Provided for non-commercial research and education use. Not for reproduction, distribution or commercial use.

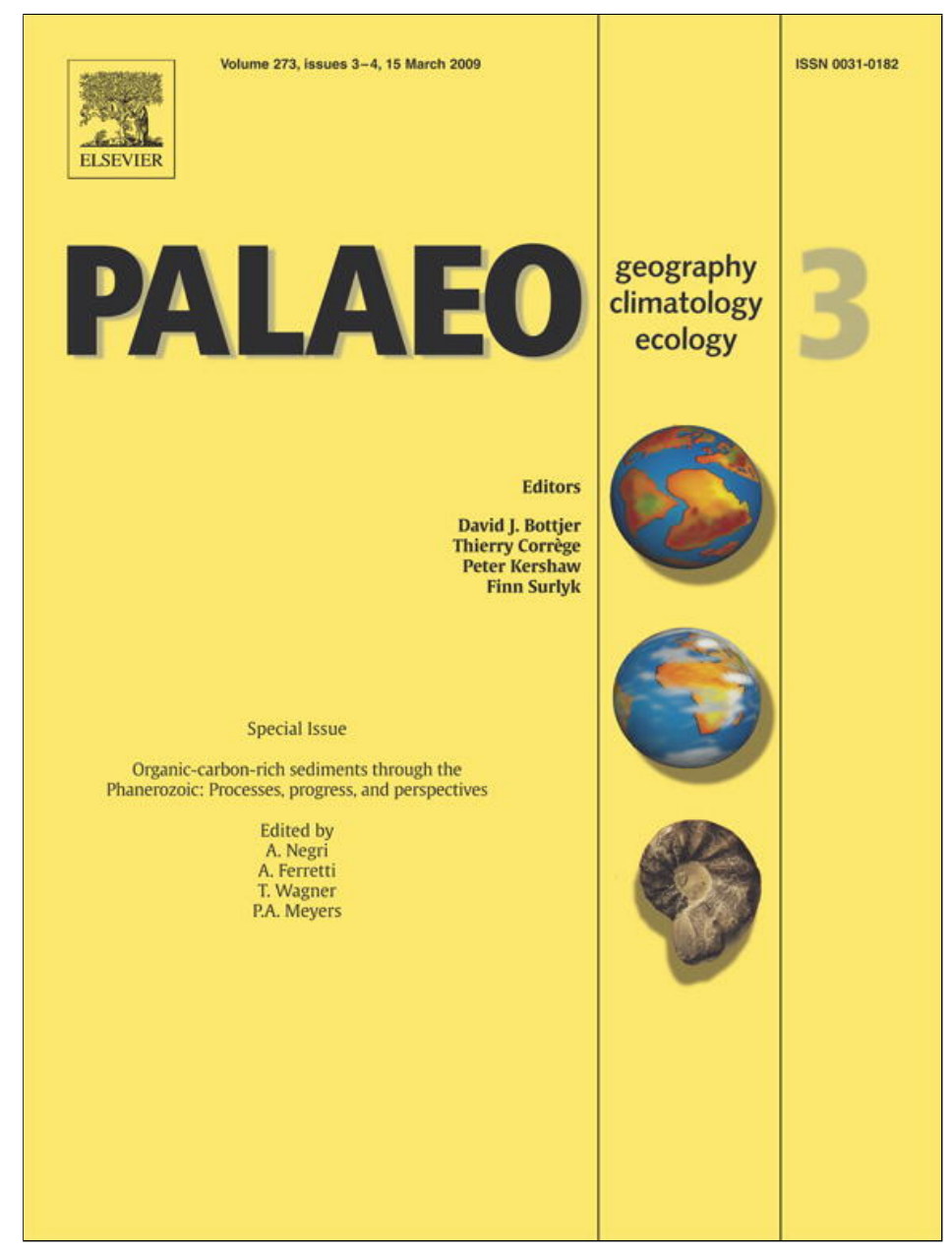

This article appeared in a journal published by Elsevier. The attached copy is furnished to the author for internal non-commercial research and education use, including for instruction at the authors institution and sharing with colleagues.

Other uses, including reproduction and distribution, or selling or licensing copies, or posting to personal, institutional or third party websites are prohibited.

In most cases authors are permitted to post their version of the article (e.g. in Word or Tex form) to their personal website or institutional repository. Authors requiring further information regarding Elsevier's archiving and manuscript policies are encouraged to visit:

http://www.elsevier.com/copyright 
Preface

\title{
Organic-carbon-rich sediments through the Phanerozoic: Processes, progress, and perspectives
}

\author{
A. Negri ${ }^{\mathrm{a}, *}$, A. Ferretti ${ }^{\mathrm{b}}$, T. Wagner $^{\mathrm{c}}$, P.A. Meyers ${ }^{\mathrm{d}}$ \\ a Dipartimento di Scienze del Mare, Università Politecnica delle Marche, Via Brecce Bianche, 60131 Ancona, Italy \\ b Dipartimento di Scienze della Terra, Università degli Studi di Modena e Reggio Emilia, Largo S. Eufemia, 41100 Modena, Italy \\ c School of Civil Engineering and Geosciences, Newcastle University, Newcastle upon Tyne, NE1 7RU, UK \\ d Department of Geological Sciences, The University of Michigan, Ann Arbor, Michigan 48109-1005 USA
}

\section{A R T I C L E I N F O}

\section{Article history:}

Received 3 October 2008

Received in revised form 4 November 2008

Accepted 13 November 2008

\section{Introduction}

This Special Issue is comprised of two related components. First, we present a summary of the occurrences of organic-carbon-rich sedimentary sequences in the Phanerozoic geological record and our overview of the evolution and current status of understanding of how they accumulated. We note especially some of the new advances in the kinds of palaeoceanographic proxies that can be used and in the more refined explanations that have emerged from these advances. The second and greater part of the Special Issue consists of fourteen research papers that provide examples of the more detailed analyses of organic-carbon-rich sedimentary sequences that can be achieved with modern techniques and that can be elegantly interpreted by specialists in these techniques.

The stimulus for this Special Issue emerged from a very successful topical session presented at the European Geophysical Union Meeting in Vienna, Austria, in April 2007. The very well attended (80-100 people) session addressed recent research advances in "Organic-carbon rich sediment through time: Past present and future, ocean and climate feedback" that included a large number of excellent oral and poster presentations. This session was the continuation of a project started in 2000 that has already yielded two well-received special issues of Palaeogeography, Palaeoclimatology, Palaeoecology. Both special issues present collections of contributions that deal with organic-carbon-rich marine sequences in different temporal windows, and both simultaneously emphasize new issues in research and reviews of existing concepts and models. The current volume forms a trilogy launched by the Special Issue "Paleoclimatic and Paleoceanographic Records in Mediterranean Sapropels and Mesozoic Black Shales" (Meyers and Negri, 2003) and continued

\footnotetext{
* Corresponding author.

E-mail address: a.negri@univpm.it (A. Negri).
}

by "Causes and Consequences of Marine Organic Carbon Burial Through Time" (Negri et al., 2006). These two volumes brought together the sapropel and black shale communities that had previously studied these organic-carbon-rich sequences separately. Moreover, their goal was to highlight the similarities and differences of these two kinds of interesting sediments, pointing to mergers of the knowledge acquired separately (e.g., Meyers, 2006).

With the current Special Issue we expand the coverage of geological time to include the Palaeozoic Era to explore the processes involved in deposition of organic-carbon-rich sequences in this huge interval of deep time (291 Ma). Investigators of Palaeozoic settings must cope with the problems of lower time resolution, seldom continuous outcrops, and general lack of undisturbed deep sea sediment sequences. Study of all palaeoceanographic processes is necessarily mediated by the available time resolution, and in the Palaeozoic the length of individual biozones is generally on the order of millions of years, which is in the same range as third-order sea-level changes. Thus, an important question in Palaeozoic sequences is whether episodes occur at different scales or belong to cycles of diverse order. Nevertheless, the study of these very old sediments cannot be neglected because they represent intervals of time that are characterized by cycling of tremendous amounts of $\mathrm{CO}_{2}$, which is one of the main factors responsible for profound changes in the Earth-Ocean-Atmosphere system and whose increase is central to modern climate changes.

Within this broad framework, a combined geochemical, palaeontological, and biological approach can address prominent examples in Earth history to assess the mechanisms operating during natural rapid global change either in greenhouse (e.g., the Cretaceous) or icehouse (e.g., Pliocene-Pleistocene) conditions. Better integration of observations of past and current climatic conditions can considerably enhance our global understanding of basic aspects of the ocean carbon system and associated climate change. In addition, a growing recognition exists that the concepts and models that have been proposed to explain how organic-carbon-rich 


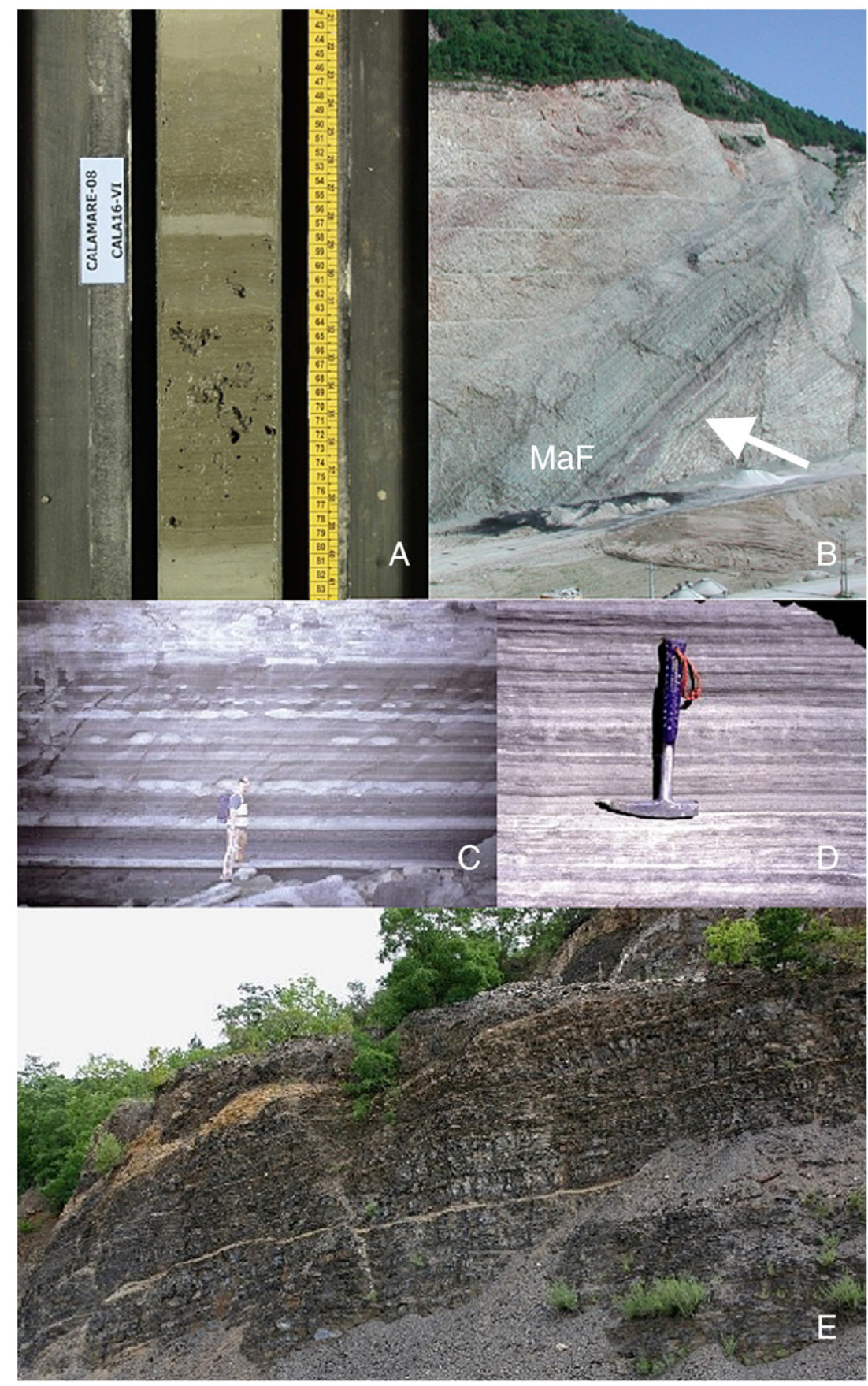

Fig. 1. Organic carbon-rich sediments through time (Photo credits: Petr Štorch, A.N., T.W. and ISMAR CNR Bologna). A: Holocene sapropel S1 in the Ionian Basin. B: The most spectacular outcrop of pelagic Cretaceous sediments in the Umbria Marche Basin of Italy: the Vispi Quarry in the Contessa Valley, near Gubbio. Sediments span 80 My and belong to four formations: Maiolica, Marne a Fucoidi, Scaglia Bianca, and Scaglia Rossa. The Marne a Fucoidi Fm. (MaF) shows evident cyclic alternations of light carbonate rich marls and darker shales related to Milankovitch orbital perturbations. Arrow indicates the Selli Level (OAE1a, late early Aptian). C: Coastal exposure of upper Cenomanian marl-black shale sequences at Mohammed Plage, North of Tarfaya, southern Morocco. Alternations of light colour carbonate-rich marls and dark organic carbon-rich black shale document regular changes in environmental and climatic conditions that occurred at orbital frequencies. D: Close-up of organic carbon-rich black shales showing mm-scale lamination indicative of extreme oxygen depletion at the time of deposition. E: Prague Basin, Kosov Quarry, Silurian black shales of the Motol Formation (Wenlock, ramosus-ellesae and lundgreni graptolite biozones).

marine sediments are deposited merit reconsideration. Are there other mechanisms for organic carbon preservation that are viable alternatives to the classical anoxia vs. productivity models?

The challenge therefore is to understand if the scientific community, notwithstanding their respective specialization in different time windows, can come to a common language and a common system that can disentangle critical elements of the earth history puzzle. This new knowledge will directly impact our ability to make realistic future projections beyond the human-scale time horizon and to assess potential carbon management scenarios, and it will represent a fundamental source of information about possible future oceanic responses to a progressively warming world. Recent observations in the equatorial Atlantic and Indian oceans that support decreasing oxygenation of the tropical ocean (Stramma et al., 2008) highlight the urgency of this topic and emphasize immediate demand for integrated research strategies.

\subsection{Note}

Two papers that should have been included in this Special Issue were by mistake published before (Bond and Wignall, 2008; Hofmann 
Table 1

Main features of the papers included in this special issue

\begin{tabular}{|c|c|c|c|c|c|c|c|c|c|c|c|c|c|c|}
\hline \multirow[t]{2}{*}{ Authors } & \multirow[t]{2}{*}{ Geological interval } & \multirow[t]{2}{*}{ Type of proxy } & \multicolumn{3}{|c|}{ Cenozoic } & \multicolumn{3}{|c|}{ Mesozoic } & \multicolumn{6}{|c|}{ Palaeozoic } \\
\hline & & & $\mathrm{Qu}$ & $\mathrm{Neo}$ & Pal & Cret & Jur & Tri & Perm & Carb & Dev & Sil & Ord & Cam \\
\hline Kim et al. (2009) & Modern & Geochemistry & & & & & & & & & & & & \\
\hline Gennari et al. (2009) & Holocene & Geochemistry & & & & & & & & & & & & \\
\hline Capozzi and Negri (2009) & Late Pleistocene-Holocene & Sequence stratigraphy & & & & & & & & & & & & \\
\hline Morigi (2009) & Late Pleistocene & Micropalaeontology & & & & & & & & & & & & \\
\hline Schwark et al. (2009) & Early Eocene & $\begin{array}{l}\text { Palaeontology, } \\
\text { geochemistry, } \\
\text { organic geochemistry }\end{array}$ & & & & & & & & & & & & \\
\hline Maerz et al. (2009) & $\begin{array}{l}\text { Late Cretaceous } \\
\text { (Coniacian-Santonian) }\end{array}$ & Geochemistry & & & & & & & & & & & & \\
\hline Hetzel et al. (2009) & $\begin{array}{l}\text { Late Cretaceous } \\
\text { (Cenomanian-Turonian) }\end{array}$ & Geochemistry & & & & & & & & & & & & \\
\hline $\begin{array}{l}\text { Hofman et al. } \\
(2008,2009)\end{array}$ & $\begin{array}{l}\text { Early Cretaceous } \\
\text { (Early Albian) }\end{array}$ & Organic geochemistry & & & & & & & & & & & & \\
\hline Mutterlose et al. (2009) & $\begin{array}{l}\text { Early Cretaceous } \\
\text { (Barremian-Albian) }\end{array}$ & $\begin{array}{l}\text { Palaeontology, } \\
\text { geochemistry }\end{array}$ & & & & & & & & & & & & \\
\hline Mailliot et al. (2009) & $\begin{array}{l}\text { Early Jurassic } \\
\text { (Pliensbachian-Toarcian) }\end{array}$ & $\begin{array}{l}\text { Micropalaeontology, } \\
\text { geochemistry }\end{array}$ & & & & & & & & & & & & \\
\hline $\begin{array}{c}\text { Bond and Wignall } \\
(2008,2009)\end{array}$ & Late Devonian & $\begin{array}{l}\text { Palaeontology, } \\
\text { geochemistry, } \\
\text { sedimentology }\end{array}$ & & & & & & & & & & & & \\
\hline Vecoli et al. (2009) & Late Ordovician-Silurian & $\begin{array}{l}\text { Palaeontology, } \\
\text { geochemistry, } \\
\text { organic geochemistry }\end{array}$ & & & & & & & & & & & & \\
\hline Armstrong et al. (2009) & Late Ordovician-early Silurian & $\begin{array}{l}\text { Organic geochemistry } \\
\text { sedimentology }\end{array}$ & & & & & & & & & & & & \\
\hline Challands et al. (2009) & Late Ordovician & $\begin{array}{l}\text { Palaeontology, } \\
\text { geochemistry, } \\
\text { organic geochemistry }\end{array}$ & & & & & & & & & & & & \\
\hline
\end{tabular}

et al., 2008). In their place in this issue (extended) abstracts are included (Bond and Wignall, 2009-this issue; Hofmann et al., 2009-this issue).

\section{Organization and content of the research papers}

The fourteen contributions to this Special Issue on organic-carbonrich sedimentation are organized by increasing geological age (see Table 1). Although this order is the reverse of how the sequences were deposited, we elected it for two reasons. First, recent and near-recent sequences are more easily studied in detail than older and often lesscomplete sequences. Second, the Pliocene-Pleistocene sapropels of the Mediterranean Sea are increasingly being considered as nearmodern analogs of Mesozoic and Palaeozoic black shales. Understanding the palaeoceanographic and palaeoclimatic processes that led to sapropel deposition therefore can improve understanding of how older organic-carbon-rich sequences were deposited. The range of geological ages that the fourteen contributions span is from the modern to the Ordovician. The papers are consequently grouped into Cenozoic, Mesozoic, and Palaeozoic units.

The Cenozoic unit of this Special Issue begins with a study by Kim et al. (2009-this issue) who investigate the modern processes involved with the transport and deposition of soil organic matter during wet and dry storms on the Têt inner shelf of the northwest Mediterranean Sea to show that these events act as a bypass corridor for delivery of land-derived organic matter to the seafloor.

Next, Gennari et al. (2009-this issue) present the results of their high resolution study of the geochemical signatures of the Holocene sapropel S1. They identify fluctuations in major and minor chemical element distributions that reveal high-frequency cyclicities that correspond to millennial and centennial-scale solar cycles. This correspondence suggests that sapropel deposition is ultimately linked to global processes, despite being confined to the Mediterranean basin.

Capozzi and Negri (2009-this issue) investigate the role of sealevel forced sedimentary processes and their impact on distribution of the Late Quaternary sapropels in the Mediterranean Sea. They examine published data on the occurrence of the complete succession of the S1-S5 sapropels and then focus on two stratigraphic sequences in the central Adriatic shelf and Middle Adriatic Depression. They find that sapropels S5 and S1 occur during periods of sea level rise recorded by the Transgressive System Tracts (Marine Isotopic Stage, MIS, 5 and 1 respectively). In contrast, sapropels S4 and S3 were deposited during the Highstand System Tracts that developed throughout MIS 5 during the late Pleistocene sequence 1. Sapropel S2 deposition, however, occurred during the warm MIS 3.3 and follows the MIS 4 sea level drop when an enhanced sediment supply is recorded during the late highstand and the falling sea level stage of sequence 1 . They also consider the possible influence of sea level lowering on Mediterranean deep water formation and conclude that although favourable conditions could be triggered by sea level oscillation, greater productivity is likely the main cause of the sedimentation of sapropels.

Morigi (2009-this issue) reconstructs the environmental changes in the Eastern Mediterranean Sea during sapropel S5 deposition by means of a high resolution benthic foraminiferal analysis in multiple 
sediment cores. The study documents that at relatively shallow depths in the bathyal environment the sea-floor was partially ventilated and that re-oxygenation had considerably increased during the late phase of S5 deposition. However, at deeper locations benthic abundance and diversity strongly decrease during sapropel $\mathrm{S} 5$, and microfauna even disappear in some levels, suggesting the establishment and maintenance of stagnant and anoxic conditions at the sea floor until the end of S5 deposition. In the deepest part of the basin, gradual repopulation of the benthic foraminiferal community at the top of the S5 layer indicates a relatively slow bottom re-oxygenation. In the southernmost site, the benthic foraminifera assemblage records a short oxygenation pulse during the $\mathrm{S} 5$ deposition that is linked to a short cold spell. Results show that the evolution of the dysoxic-anoxic conditions as well as the re-oxygenation pattern at the end of the stagnant period was strongly dependent on the basin morphology.

Schwark et al. (2009-this issue) develop a depositional model for the Eocene "Pesciara di Bolca" Konservat-Lagerstätte based on sedimentological, palaeocological, and detailed organic geochemical data. Their data indicate that the sequence was deposited in the stagnant bottom waters of a lagoonal-like basin located on an extended carbonate platform that was sheltered from open marine waters by a submarine threshold. The high abundance of highly branched isoprenoids in extractable bitumens suggests that run-off from nearby land areas provided nutrients to support an algal community dominated by diatoms. Plant macrofossils, amber, spores and pollen, and also lipid compositions indicate notable input of land plant organic matter to the lagoon. The redox regime in general was strongly reducing, as evidenced by the high concentration of sulfur vs. organic carbon and excellent kerogen preservation. Molecular indices suggest a highly stratified water column with anoxic saline bottom water and fresher surface waters, and traces of derivatives of isorenieratane, the green sulfur bacteria molecular marker, indicate euxinic conditions existed at times in the photic zone. The authors conclude that the depositional setting was comparable to the Solnhofen limestones, but without the high salinities postulated for the latter.

Moving into the Mesozoic, März et al. (2009-this issue) investigate black shales from the Coniacian-Santonian OAE3 at two locations in different palaeo-water depths on the Demerara Rise off Surinam to identify systematic variations in marine and detrital sediment contribution, depositional processes, and bottom water redox. Using a wide range of redox proxies, including $\mathrm{Fe} / \mathrm{S}, \mathrm{P} / \mathrm{Al}, \mathrm{C} / \mathrm{P}$, and redox-sensitive trace metals, and $\mathrm{P}$ speciation, electron microscopy, X-ray diffraction, they conclude that anoxic to sulfidic bottom water and sediment conditions existed throughout the deposition of the black shales. These extreme redox conditions were periodically punctuated by shorttermed periods with less reducing bottom waters irrespective of palaeo-water depth. Due to strong similarities of the studied sections with the stratigraphically older OAE2 black shale on the Demerara Rise, the authors suggest that the primary mechanisms controlling continental supply and ocean redox were time-invariant and kept the western equatorial Atlantic margin widely anoxic over millions of years.

Hetzel et al. (2009-this issue) reconstruct the dynamics of deep ocean redox palaeoconditions during deposition of CenomanianTuronian OAE2 black shales on the Demerara Rise. Focusing on sulfurcarbon-metal relationships and especially distribution patterns of iron and sulfur speciation, sulfur isotope partitioning, and enrichments of redox-sensitive and sulfide forming trace metals, they identify euxinic conditions with at least temporarily free hydrogen sulfide in the water column, similar to the modern deep Black Sea. A change to reducing but non-sulfidic conditions to allow reductive Fe and Co mobilization in oxygen-depleted nearshore sediments is inferred from elevated $\mathrm{Fe} / \mathrm{Al}$ and $\mathrm{Co} / \mathrm{Al}$ ratios. Extremely low $\mathrm{Mn} / \mathrm{Al}$ ratios further support the existence of an extended coastal upwelling oxygen-minimum-zone off tropical South America. Finally, the authors discuss a change in the trace metal inventory of seawater. They postulate the enlargement of euxinic depositional areas at the global onset of OAE2 that would have led to a drawdown of the seawater trace metal reservoir, based on the general observation that hypoxic to euxinic environments form a sink for trace metals (e.g., Brumsack, 2006).

Hofmann et al. (2008, 2009-this issue) address aspects of climateocean coupling off northwest Africa during the Lower Albian OAE1b. They present high resolution records of organic and inorganic geochemical proxies from DSDP Site 545 on the Mazagan Plateau that document a complex and rapid environmental change for onshore continental climate and the offshore upwelling system associated with OAE1b. TEX86-based SST estimates reveal an abrupt rise of $\sim 3{ }^{\circ} \mathrm{C}$ concurrent with a more than two-fold increase in accumulation rates for organic-carbon and siliciclastic sediment components, with an influx of overall finer grained sediment as inferred from $\mathrm{Si} / \mathrm{Al}$ and $\mathrm{Zr} / \mathrm{Al}$ ratios. This new set of data supports the conclusion that warming associated with OAE1b resulted in an attenuation of the NE trade wind system over central Africa and a weakening of local upwelling conditions off NW Africa. The authors invoke higher continental runoff that may have supplied excess nutrients to the eastern North Atlantic that in turn fostered greater production of organic matter and finally led to black shale deposition.

Mutterlose et al. (2009-this issue) analyze the macrofaunal content and bulk geochemistry $\left(\delta^{13} \mathrm{C}, \delta^{18} \mathrm{O}\right)$ of the expanded organic-carbonrich mudstone sequence of Barremian-early Aptian age exposed in northern Germany, including the mid early Aptian "Fischschiefer" equivalent of the OAE1a. They find that the sequence of finely laminated black shales ("Blätterton") with organic carbon contents as high as $7 \%$ is interbedded with dark and carbonate-poor clays on a decimeter to several meter scale that record repetitive fluctuations of salinity driven stratification of the water column in relation to more humid conditions in the hinterland. A distinctive positive $\delta^{13} \mathrm{C}$ excursion of $\sim 4 \%$ o preserved in belemnite guards is found to correlate with the global positive $\delta^{13} \mathrm{C}$ excursion of mid-early Aptian age following the OAE1a, providing the first record of the positive carbon excursion for the Boreal Realm. A concomitant shift in $\delta^{18} \mathrm{O}$ of about $2 \%$ is interpreted as a distinct SST decrease of $\sim 8^{\circ} \mathrm{C}$, a trend that is also reflected by changes in lithology and organic carbon burial from the thick early Barremian Hauptblätterton to thin laminites in the late Barremian. The observations from this study suggest a direct temperature control on peak anoxic conditions followed by repetitive and short termed redox fluctuations.

Mailliot et al. (2009-this issue) present records of calcareous nannofossil and benthic foraminifer assemblages and geochemistry of two sections from the partly enclosed Causses Basin of the epicontinental shelf of northwest Tethys to infer a progressive environmental deterioration passing from the Late Pliensbachian to the Early Toarcian. The data show that the palaeoenvironmental deterioration culminated during the Early Toarcian OAE with a drastic decrease in nannoplankton production and a temporary disappearance of benthic foraminifers, the latter likely in response to bottom water anoxia.

The Palaeozoic unit starts with a contribution from Bond and Wignall (2008, 2009-this issue), who globally revisit the Frasnian-Famennian (Late Devonian) mass extinction, comparing new sections in the USA and Europe (France, Germany, Poland) with published data from locations in Canada, Australia and China. Several high-frequency relative sea-level changes are common to the multiple sites, supporting a transgression-anoxia-extinction link for the late Frasnian to earliest Famennian interval.

Two papers deal with Upper Ordovician-Silurian sediments from the North African margin of Gondwana. Armstrong et al. (2009-this issue) examine Upper Ordovician-Silurian black shales of Jordan. They provide evidence for a consistent increase in photic zone primary productivity during ice melting and conclude that increased flux of sinking organic matter led to euxinia extending from the photic zone to the sediment water interface as evidenced by the widespread presence of isorenieratane derivatives, which resulted in improved organic matter preservation. Vecoli et al. (2009-this issue) integrate a palynological and palynofacies analysis with organic carbon isotope 
measurements in southern Tunisia. The earliest Wenlock ("Ireviken Event") and late Ludlow ("Lau Event") isotopic excursions are documented for the first time in high-latitude Gondwana, corroborating the hypothesis that these excursions reflect global changes in the oceanic system. Both isotopic excursions are interpreted within a wide palaeogeographic scenario. The authors propose an extended period of black shale deposition from Rhuddanian to early Wenlock times over the North African Gondwanan margin, associated with a coastal upwelling-promoted productivity increase and a decrease in diversity of the marine microplanktonic communities.

In the final paper on Palaeozoic palaeoceanography, Challands et al. (2009-this issue) discuss the origin of grey-black shale cycles within the Upper Ordovician (Upper Katian) succession of the Welsh Basin. Using a multi-proxy approach, they document high photic zone productivity comparable to that of modern coastal upwelling systems and persistent dysoxic to anoxic conditions in the water column, interpreting these deposits to be the result of a complex interaction of productivity and preservation.

\section{Acknowledgements}

Special thanks are due to Petr Štorch, who started with us on this adventure but had to drop out because of other demands on his time. His contributions were important to the success of the EGU session.

We are particularly indebted to those important individuals who carefully and conscientiously reviewed the manuscripts that we received for this Special Issue. We acknowledge their excellent contributions by naming them here:

Alessandro Amorosi, Achim Bechtel, Carlton Brett, Hans-Jürgen Brumsack, James Casford, Anna M. Cruse, Olaf Dellwig, Elisabetta Erba, Karl Föllmi, Oliver Friedrich, David Gallego-Torres, Luca Giusberti, Michael Hermoso, Carmen Huguet, Steve Kershaw, Christopher Junium, Timothy W. Lyons, Axel Munnecke, Alex Page, Florentin Paris, Tatsuhiko Sakamoto, Lorenz Schwark, Jan Schwarzbauer, Caroline Slomp, Federico Spagnoli, Helen M. Talbot, Ellen Thomas, Steven Turgeon, Paul Wignall, Jan Zalasiewicz.

Thanks are due to the authors of the individual research papers for their hard work and for their efforts to meet the generally stringent time tables we imposed on them.

Finally we thank Femke Wallien, who encouraged us to organize a third special issue dealing with "black shales", Jules Snelleman, and Fred Kop, who together provided us guidance throughout our period as guest editors.

\section{References}

Armstrong, H.A., Abbott, G.D., Turner, B.R., Makhlouf, I.M., Aminu Bayawa, M., Pedentchouk, N., Peters, H., 2009. Black shale deposition in an Upper OrdovicianSilurian permanently stratified, peri-glacial basin, southern Jordan. Palaeogeography, Palaeoclimatology, Palaeoecology 273, 368-377 (this issue).

Bond, D.P.G., Wignall, P.B., 2008. The role of sea-level change and marine anoxia in the Frasnian-Famennian (Late Devonian) mass extinction. Palaeogeography. Palaeoclimatology, Palaeoecology 263,107-118.
Bond, D.P.G., Wignall, P.B., 2009. Extended Abstract of "The role of sea-level change and marine anoxia in the Frasnian-Famennian (Late Devonian) mass extinction". Palaeogeography, Palaeoclimatology, Palaeoecology 273, 365-367 (this issue).

Brumsack, H.-J., 2006. The trace metal content of recent organic carbon-rich sediments: implications for Cretaceous black shale formation. Palaeogeography, Palaeoclimatology, Palaeoecology 232, 344-361.

Capozzi, R., Negri, A., 2009. Role of sea-level forced sedimentary processes on the distribution of organic carbon-rich marine sediments: a review of the Late Quaternary sapropels in the Mediterranean Sea. Palaeogeography, Palaeoclimatology, Palaeoecology 273, 249-257 (this issue).

Challands, T.J., Armstrong, H.A., Maloney, D.P., Davies, J.R., Wilson, A., Owen, A.W., 2009. Organic-carbon deposition and coastal upwelling at mid-latitude during the Upper Ordovician (Late Katian): A case study from the Welsh Basin, UK. Palaeogeography, Palaeoclimatology, Palaeoecology 273, 395-410 (this issue).

Gennari, G., Tamburini, F., Ariztegui, D., Hajdas, I., Spezzaferri, S. 2009. Geochemical evidence for high-resolution variations during deposition of the Halocene S1 sapropel on the Cretan Ridge, Eastern Mediterranean. Palaeogeography, Palaeoclimatology, Palaeoecology 273, 239-248 (this issue).

Hetzel, A., Böttcher, M.E., Wortmann, U.G., Brumsack, H.-J. 2009. Paleo-redox conditions during OAE 2 reflected in Demerara Rise sediment geochemistry (ODP Leg 207). Palaeogeography, Palaeoclimatology, Palaeoecology 273, 302-328 (this issue).

Hofmann, P., Stüsser, I., Wagner, T., Schouten, S., Sinninghe Damsté, J.S., 2008. Climateocean coupling off North-West Africa during the Lower Albian: the Oceanic Anoxic Event 1b. Palaeogeography, Palaeoclimatology, Palaeoecology 262, 157-165.

Hofmann, P., Stüsser, I., Wagner, T., Schouten, S., Sinninghe Damsté, J.S. 2009. Abstract of "Climate-ocean coupling off North-West Africa during the Lower Albian: the Oceanic Anoxic Event 1b". Palaeogeography, Palaeoclimatology, Palaeoecology 273, 329 (this issue).

Kim, J.-H., Buscail, R., Bourrin, F., Palanques, A., Sinninghe Damsté, J.S., Bonnin, J., Schouten, S. 2009. Transport and depositional process of soil organic matter during wet and dry storms on the Têt inner shelf (NW Mediterranean). Palaeogeography, Palaeoclimatology, Palaeoecology 273, 228-238 (this issue).

Mailliot, S., Mattioli, E., Bartolini, A., Baudin, F., Pittet, B., Guex, J. 2009. Late Pliensbachian Early Toarcian (Early Jurassic) environmental changes in an epicontinental basin of NW Europe (Causses area, central France): a micropaleontological and geochemical approach. Palaeogeography, Palaeoclimatology, Palaeoecology 273, 346-364 (this issue).

März, C., Beckmann, B., Franke, C., Vogt, C., Wagner, T., Kasten, S. 2009. Geochemical environment of the Coniacian-Santonian western tropical Atlantic at Demerara Rise. Palaeogeography, Palaeoclimatology, Palaeoecology 273, 286-301 (this issue).

Meyers, P.A., 2006. Paleoceanographic and paleoclimatic similarities between Mediterranean sapropels and Cretaceous black shales. Palaeogeography, Palaeoclimatology, Palaeoecology 235, 305-320.

Meyers, P.A., Negri, A., 2003. Paleoclimatic and paleoceanographic records in Mediterranean Sapropels and Mesozoic black shales. Special Issue, Palaeogeography, Palaeoclimatology, Palaeoecology 190,1-480.

Morigi, C. 2009. Benthic environmental changes in the Eastern Mediterranean Sea during sapropel S5 deposition. Palaeogeography, Palaeoclimatology, Palaeoecology 273, 258-271 (this issue)

Mutterlose, J., Pauly, S., Steuber, T. 2009. Temperature controlled deposition of early Cretaceous (Barremian-early Aptian) black shales in an epicontinental sea. Palaeogeography, Palaeoclimatology, Palaeoecology 273, 330-345 (this issue).

Negri, A., Wagner, T., Meyers, P.A., 2006. Causes and consequences of marine organic carbon burial through time. Palaeogeography, Palaeoclimatology, Palaeoecology $235,1-320$.

Schwark, L., Ferretti, A., Papazzoni, C.A., Trevisani, E. 2009. Organic geochemistry and paleoenvironment of the Early Eocene "Pesciara di Bolca" Konservat-Lagerstätte, Italy. Palaeogeography, Palaeoclimatology, Palaeoecology 273, 272-285 (this issue).

Stramma, L., Johnson, G.C., Sprintall, J., Mohrholz, V., 2008. Expanding oxygen-minimum zones in the tropical oceans. Science 320 (5876), 655-658.

Vecoli, M., Riboulleau, A., Versteegh, G., Trevisani, E. 2009. Palynology, organic geochemistry and carbon isotope analysis of a latest Ordovician through Silurian clastic succession from borehole Tt1, Ghadamis Basin, southern Tunisia, North Africa: palaeoenvironmental interpretation. Palaeogeography, Palaeoclimatology, Palaeoecology 273, 378-394 (this issue). 